\title{
PERBEDAAN PEMBELAJARAN MELALUI MULTIMEDIA INTERAKTIF DAN MELALUI BUKU TEKS TERHADAP HASIL BELAJAR SISWA PADA MATERI PECAHAN KELAS IV SDN GADANG 01 MALANG
}

\author{
Nur Farida, Sri Rahayu \\ Universitas Kanjuruhan Malang, \\ Email: faridanaufal22@gmail.com, yykisk728@gmail.com
}

\begin{abstract}
Abstrak: Penggunaan media dalam proses belajar mengajar mempermudah kemampuan siswa untuk memahami materi. Seiring berkembangnya teknologi informasi, pembelajaran matematika saat ini, khususnya pada materi mangurutkan pecahan, yaitu dengan memanfaatkan teknologi komputer untuk membuat dan mempresentasikan media pembelajaran. Salah satu media pembelajaran adalah multimedia interaktif.Tujuan dalam penelitian ini adalah untuk mengetahui adakah perbedaan pembelajaran melalui multimedia interaktif dan melalui buku teks terhadap hasil hasil belajar siswa pada materi pecahan kelas IV, SDN Gadang 01 Malang. Penelitian ini menggunakan penelitian kuantitatif. Sampel penelitian adalah seluruh siswa kelas IV A dan IV B, SDN Gadang 01 Malang. Instrumen penelitian yang digunakan tes. Teknik analisis yang digunakan adalah uji-t. Hasil penelitian menunjukkan bahwa ada perbedaan antara pembelajaran melalui multimedia interaktif dan melalui buku teks terhadap hasil belajar siswa, dimana hasil yang diperoleh pada kelas eksperimen memiliki mean 65,89 dengan standar deviasi 18,878 lebih besar daripada kelas kontrol yang memiliki mean 53,33 dengan standar deviasi 32,471. Hasil gain score menunjukkan selisih antara nilai pretest dan posttest didapatkan pada kelas eksperimen dengan hasil rata-rata gain score yaitu 0,7 yang masuk dalam kategori tinggi. Sementara itu, hasil perhitungam uji t didapatkan $\mathrm{t}=2,089 ; \mathrm{F}=15,285$ dan signifikansi 2-tail 0,40/0,41 lebih kecil dari signifikansi 0,05, maka Ho ditolak dan Ha diterima. Artinya, ada perbedaan yang signifikan pada penggunaan multimedia pembelajaran interaktif terhadap hasil belajar siswa di SDN Gadang 01 Malang.
\end{abstract}

Kata-Kata Kunci: Model pembelajaran interaktif, buku teks, hasil belajar, pecahan.

\begin{abstract}
The use of media in learning process facilitates the ability of students to understand the material. As the development of information technology, the learning of mathematics at this time particularly in sorting fraction subject matter utilizes computer technology to create and present the learning media. One of the learning media is Interactive multimedia. The objectives of this research is to know is there any difference in learning through interactive multimedia and textbooks toward fourth grade students' learning outcome in the fractions subject matter, SDN Gadang 01 Malang. This study uses a quantitative research. The samples are all students of IV A and IV B class, SDN Gadang 01 Malang. The research instrument is tests. The technique to analyze the data is the t-test. The results of the research show that there is a difference between learning through interactive multimedia and through textbooks on student learning outcomes, where the mean of the experimental class is 65.89 with standard deviation 18.878 is greater than the control class that has a mean 53.33 with standard deviation 32.471. The results of gain score show the difference between pretest and posttest score of the experimental class with average score 0.7 which is in the high category. Meanwhile, the results of t-test obtained $t=2.089 ; \mathrm{F}=15.285$ and two-tail significance $0.40 / 0.41$ less than 0.05 , thus Ho is rejected and $\mathrm{Ha}$ is accepted. It means that there is significant difference in the use of multimedia interactive learning toward the learning outcomes of students at SDN Gadang 01 Malang.
\end{abstract}

Keywords: Interactive learning model, textbooks, learning outcomes, fractions.

\section{PENDAHULUAN}

Pendidikan adalah usaha sadar yang bertujuan untuk mengembangkan kualitas manusia. Sebagai suatu kegiatan yang sadar akan tujuan, maka dalam pelaksanaanya me- rupakan proses yang berkesinambungan dalam setiap jenis dan jenjang pendidikan, semuanya berkaitan dalam suatu sistem pendidikan yang integral dan terpadu (Djamarah, 2005). 
Pembelajaran adalah membelajar-kan siswa menggunakan asas pendidikan maupun teori belajar, merupakan penentu utama keberhasilan pendidikan. Pem-belajaran merupakan komunikasi dua arah, mengajar dilakukan oleh pihak guru sebagai pendidik, sedangkan belajar dilakukan oleh peserta didik atau siswa (Sagala, 2010:61).

Pembelajaran Matematika di Sekolah Dasar (SD) merupakan salah satu kajian yang selalu menarik untuk dikemukakan, anak usia SD sedang mengalami perkembangan dalam tingkat berpikirnya yang sedang pada tahapan prakongkrit ke kongkrit dan menuju tahapan abstrak. Sedangkan Matematika adalah ilmu deduktif, aksiomatik, formal, hierarkis abstrak, bahasa simbol padat arti. Oleh karena itu, diperlukan kemampuan khusus dari seorang guru untuk menjembatani antara dunia anak yang belum berpikir deduktif untuk dapat mengerti dunia matematika yang bersifat deduktif (Muslim, 2012).

Buku teks adalah buku pelajaran dalam bidang studi tertentu, yang merupakan buku standar, yang disusun oleh para pakar dalam bidang itu untuk maksud-maksud dan tujuan instruksional, yang dilengkapi dengan saranasarana pengajaran yang serasi dan mudah dipahami oleh para pemakainya di sekolahsekolah dan perguruam tinggi sehingga dapat menunjang sesuatu program pengajaran (Tarigan dan Tarigan, 2009:13).

Media merupakan salah satu sarana belajar yang membantu siswa untuk memahami suatu materi yang disampaikan. Penggunaan media tersebut sangat bermanfaat terhadap proses kegiatan belajar yaitu mempermudah kemampuan siswa untuk memahami suatu materi. Pemanfaat multimedia interaktif dalam menyampaikan materi pecahan merupakan salah satu cara untuk perbaikan dalam sistem pembelajaran termasuk penyajian materi. Tujuan digunakan multimedia interaktif adalah memudahkan siswa dalam menangkap dan memahami materi khususnya mengurutkan pecahan.

Media pembelajaran yang dirancang dengan baik dapat merangsang timbulnya proses/dialog mental pada diri siswa. Dengan perkataan lain, terjadi komunikasi siswa antara siswa dengan media atau secara tidak langsung tentunya antara siswa dengan penyalur pesan (guru), dengan demikian dapat dikatakan bahwa proses belajar-mengajar telah terjadi.

\section{METODE}

Pendekatan yang digunakan dalam penelitian ini adalah pendekatan kuantitatif. Penelitian Kuantitatif adalah penelitian yang digunakan untuk meneliti pada populasi atau sampel tertentu, teknik pengambilan sampel pada umumnya dilakukan secara random, pengumpulan data menggunakan instrumen penelitian, analisis data bersifat kuantitatif/statistik dengan tujuan untuk menguji hipotesis yang telah ditetapkan (Sugiono, 2014:14). Jenis penelitian pada penelitian pada penelitian ini yaitu penelitian kuasieksperimen (eksperimen semu). Darmawan (2013:51) menyatakan pada ekperimen kuasi ini rumusan masalah harus mengandung hubungan kausal atau sebab akibat antar variabel yang sudah ditemukan pada saat merumuskan latar belakang. Selain itu, dalam penelitian ini melibatkan dua kelas paralel yaitu kelas yang bertindak sebagai kelas eksperimen (kelas yang diberi perlakuan) dan kelas yang bertindak sebagai kelas kontrol (tanpa pemberian perlakuan) sesuai dengan kriteria penelitian eksperimen semu.

Pada penelitian ini terdapat 2 variabel yakni variabel independen (variabel bebas) dan variabel dependen (variabel terikat). Variabel independen pada penelitian ini adalah penggunaan muitimedia interaktif sedangkan variabel dependen dalam penelitian ini adalah hasil belajar siswa. Populasi dari penelitian ini adalah siswa kelas IV A dan IV B di SDN 
Gadang 01 Kota Malang dengan jumlah 78 siswa. Peneltian ini menggunakan teknik nonrandom sampling. Teknik nonrandom sampling adalah cara pengambilan sampel yang semua objek atau elemen populasinya tidak dimiliki kesempatan yang sama untuk dipilih sebagai anggota sampel. Pengambilan sampel pada teknik nonrandom sampling pada penelitian ini menggunakan Judgment Sampling. Peneliti mengambil sampel kelas IV A dan kelas IV B. Kelas IV A bertindak sebagai kelas kontrol (tanpa diberi perlakuan) sedangkan kelas IV B bertindak sebagai kelas Instrumen (diberi perlakuan). Jumlah sampel sebanyak 78 siswa.

Uji analisis data dilakukan melalui tiga cara, yaitu 1) Uji Normalitas, ada beberapa teknik yang dapat digunakan untuk menguji normalitas data, antara lain: dengan kertas peluang normal, uji chi-kuadrat, uji liliefors, dengan teknik Kolmogorov-Smirnov, dan dengan SPSS. Untuk uji normalitas secara manual dapat menggunakan rumus ChiKuadrat:

Untuk uji normalitas data pada penelitian ini menggunakan keluaran Tes of Normality. Dengan demikian, normalitas dipenuhi jika hasil uji tidak signifikan untuk suatu taraf signifikan $(\alpha)$ tertentu (biasanya $\alpha=$ $0,05$ atau $\alpha=0,01)$. 2) Uji Homogenitas, untuk menghitun guji homogenitas secara manual dapat dengan menggunakan rumus variansi gabungan. Dengan demikian, kehomogenan dipenuhi jika hasil uji tidak signifikan untuk suatu taraf signifikansi $(\alpha)$ tertentu (biasanya $\alpha$ $=0,05$ atau $\alpha=0,01$ ). Sebaliknya, jika hasil uji signifikan maka kehomogenan tidak dipenuhi.

3) Uji Hipotesis, pada penelitian ini menggunakan uji-t. Untuk menguji hipotesis peneliti menggunakan uji-t dengan menentukan taraf signifikan sebesar 5\% oleh karena itu jika nilai sig yang diperoleh kurang dari 0,05 maka Ha diterima dan Ho ditolak, dan jika nilai sig lebih dari 0,05 maka Ho yang diterima dan $\mathrm{Ha}$ ditolak.

\section{Desain Penelitian}

Desain penelitian yang digunakan dalam penelitian ini adalah desain kelompok kontrol pretest-posttest acak (randomized pretestposttest control group design) yang divisualisasikan sebagai berikut.

\section{Tabel 3.1 Desain Penelitian}

\begin{tabular}{|c|c|c|c|}
\hline Kelompok & Pretest & Perlakuan & Posttest \\
\hline A & T1 & X1 & T2 \\
\hline B & T1 & X2 & T2 \\
\hline
\end{tabular}

Keterangan: $\mathrm{A}=$ kelompok eksperimen (multimedia interaktif); $\mathrm{B}=$ kelompok kontrol (buku teks saja); $\mathrm{T} 1=$ tes awal yang sama pada kedua kelompok (pretest); $\mathrm{X} 1=$ pemberian materi dengan multimedia interaktif; $\mathrm{X} 2=$ pemberian materi dengan buku teks saja; $\mathrm{T} 2=$ tes akhir yang sama pada kedua kelompok (posttest)

\section{HASIL DAN PEMBAHASAN}

\section{Uji Validitas}

Hasil analisis validitas ditunjukkan dengan memban dingkan nilai $r$ hitung dengan nilai $r$ tabel $(0,443)$. Apabila $r$ hitung $>0,443$ makabutir soal yang disajikan adalah valid. Hasil analisis validitas yang didistribusikan kepada kelas kontrol yang menggunakan media pembelajaran buku teks (X1) yaitu kelas IVA 39 responden. Hasil analisis validitas ditunjukkan dengan membandingkan nilai $r$ hitung dengan nilai $r$ tabel $(0,380)$. Apabila $r$ hitung $>$ 0,380 maka butir soal yang disajikan adalah valid. Hasil analisis validitas yang didistribusikan kepada kelas eksperimen yang menggunakan multimedia interaktif (X2) yaitu kelas IV B dengan 39 responden. Hasil reliabilitas menunjukkan nilai Alpha Cronbach dari masing-masing variabel, yaitu 0,639 untuk variable kelas control menggunakan media buku teks saja (X1) dan 0,778 untuk variable kelas eksperimen menggunakan multimedia interaktif (X2), dimana seluruh variable bebas tersebut memiliki status reliabilitas baik. 


\section{Uji Normalitas}

Untuk menghitung uji normalitas data pada penelitian ini, peneliti menggunakan bantuan SPSS 16,0. Peneliti menentukan taraf signifi- kansi sebesar 5\%. Dari hasil perhitungan menggunakan SPSS 16,0 diperoleh hasil yang dapat dilihat pada tabel 4.1.

Tabel 4.1 Hasil Uji Normalitas Nilai Pretes dengan SPSS 16.0

\begin{tabular}{|l|c|c|c|c|c|c|}
\hline \multirow{2}{*}{\multicolumn{1}{|c|}{ Kelas }} & \multicolumn{3}{|c|}{ Kolmogorov-Smirnov } & \multicolumn{3}{c|}{ Shapiro-Wilk } \\
\cline { 2 - 7 } & Statistic & df & Sig. & Statistic & df & Sig. \\
\hline Pretes Kelas Kontrol & .260 & 39 & .000 & .827 & 39 & .000 \\
Kelas Eksperimen & .271 & 39 & .000 & .725 & 39 & .000 \\
\hline
\end{tabular}

Berdasarkan tabel di atas untuk analisis normalitas data, tampak bahwa pada hasil kelas eksperimen yang diuji dengan KolmogorovSmirnov (sig: 0,200 > 0,05) dan Shapiro-Wilk (sig: 0,594 > 0,05) masing-masing menunjukkan angka dengan taraf signifikansi lebih besar dari 0,05 , sedangkan untuk kelas kontrol yang diuji dengan Kolmogorov-Smirnov (sig: 0,187 $>0,05$ ) dan Shapiro-Wilk (sig: 0, $564>0,05$ ) masing-masing juga menunjukkan angka-angka dengan taraf signifikansi lebih besar dari 0,05. Jadi, secara keseluruhan dapat disimpulkan bahwa pada semua unit analisis data terdistribusi dengan normal.

\section{Uji Hipotesis}

Tabel 4.2 Hasil Analisis Mean dan Standar Deviasi Nilai Postes

\begin{tabular}{|l|c|c|c|c|}
\hline \multicolumn{1}{|c|}{ Kelompok } & N & Mean & Std. Devination & Std. Error Mean \\
\hline Nilaikelaseksperimen & 39 & 65.89 & 18.878 & 3.023 \\
kelaskontrol & 39 & 53.33 & 32.471 & 5.199 \\
\hline
\end{tabular}

Hasil uji analisis Mean dan Standar Deviasi pada kelas control dan kelas eksperimen adalah berbeda. Hasil mean dan standar deviasi pada kelas control mencapai 53.33 dan
32.471, sedangkan hasil pada kelas eksperimen mencapai 65.89 dan 18.878. Sementara Error Mean dari masing-masing kelas mencapai 3.023 dan 5.199.

Tabel 4.3 Uji T-test

\begin{tabular}{|c|c|c|c|c|c|c|c|c|c|}
\hline & \multicolumn{2}{|c|}{$\begin{array}{l}\text { Levene's Test } \\
\text { for Equality of } \\
\text { Variances } \\
\end{array}$} & \multicolumn{7}{|c|}{ t-test for Equality of Menas } \\
\hline & \multirow[b]{2}{*}{$\mathrm{F}$} & \multirow[b]{2}{*}{ Sig. } & \multirow[b]{2}{*}{$\mathrm{t}$} & \multirow[b]{2}{*}{ df } & \multirow[b]{2}{*}{$\begin{array}{c}\text { Sig. } \\
(2- \\
\text { tailed }) \\
\end{array}$} & \multirow[b]{2}{*}{$\begin{array}{c}\text { Mean } \\
\text { Differenc } \\
\mathrm{e} \\
\end{array}$} & \multirow[b]{2}{*}{$\begin{array}{l}\text { Std. Error } \\
\text { Difference }\end{array}$} & \multicolumn{2}{|c|}{$\begin{array}{l}\text { 95\% Confidence } \\
\text { Interval of the } \\
\text { Difference }\end{array}$} \\
\hline & & & & & & & & Lower & Upper \\
\hline Nilai Equal variancesassumed & 15.285 & .000 & 2.089 & 76 & .040 & 12.56410 & 6.01450 & .58518 & 24.54303 \\
\hline Equal variancesnot assumed & & & 2.089 & 61.056 & 0.41 & 12.56410 & 6.01450 & .53758 & 24.59063 \\
\hline
\end{tabular}

Dari hasil uji-t, diketahui $\mathrm{t}=2.089 ; \mathrm{F}=$ 15.285 dan signifikansi 2-tail lebih kecil dari signifikansi 0,05. Pada kelas eksperimen diperoleh mean 65.89 dengan standar deviasi 18.878 lebih besar daripada kelas kontrol yang memiliki mean 53.33 dengan standar deviasi 32.471. Data tersebut menunjukkan bah-wa ada perbeda anantara pembelajaran Melalui multimedia interaktif dan melalui buku teks terhadap hasil belajar siswa. 
Berdasarkan hasil analisis, hipo-tesis nol ditolak dan hipotesis alternative diterima. Dari hasil analisis dengan menggunakan independent sample t-test didapatkan bahwa mean kelas eksperimen lebih tinggi daripada kelas kontrol. Kelas eksperimen memiliki mean 65.89 dan kelas kontrol mean 53.33. Siswa yang belajar dengan menggunakan multimedia interaktif jauh "Wahyudi" memperoleh hasil belajar yang lebih tinggi dibandingkan dengan siswa yang belajar dengan buku teks. Hasil uji t hasil belajar diperoleh taraf signifikansi adalah .000 lebih kecil dari 0,05 ( $\mathrm{p}<0,05)$. Berdasarkan perolehan nilai $\alpha$, maka disimpulkan bahwa ada perbedaan hasil belajar siswa yang menggunakan multimedia dengan yang menggunakan buku teks saja.

Berdasarkan ranah afektif, maka hasil minat atau sikap tiap peserta didik pada pelajaran matematika khususnya materi mangurutkan pecahan masih rendah/kurang. Hal ini disebabkan karena dalam pembelajaran di kelas IV Ainihan yang menggunakan media buku teks saja, sehingga siswa merasa bosan dan tidak tertarik untuk mempelajari matematika. Bila sikap peserta didik tergolong rendah/kurang, maka peserta didik harus berusaha meningkatkan sikap dan minatnya dengan bimbingan pendidik. Oleh karena itu, pendidik harus mampu menggunakan media pembelajaran yang menarik. Berdasarka ranah afektif, hasil minat atau sikap tiap peserta didik pada pelajaran matematika khususnya materi mengurutkan pecahana dalah tinggi/baik. Hal ini disebabkan karena dalam pembelajaran di kelas IV B ini menggunakan multimedia. Multimedia interaktif adalah salah satu media yang menarik karena didalamnya memuat gambar, audio, video, maupun animasi, sehingga dapat menimbulkan ketertarikan dan minat siswa dalam mempelajari matematika khususnya materi mengurutkan pecahan. Bila sikap peserta didik tergolong tinggi/baik, maka peserta didik harus berusaha mempertahankannya.

\section{PEMBAHASAN}

Proses mengintegrasikan teks dan gambar animasi juga video yang relevan itu adalah langkah kunci dalam pembelajaran yang penuh makna (Mayer, 2009). Proses ini bisa difasilitasi dengan penggunaan multimedia dalam pembelajaran daripada hanya dengan buku teks saja yang berdampak pada perolehan hasil belajar.Dengan menggunakan multimedia siswa dapat melihat, mendengar bahkan berinteraksi sehingga keterlibatan indera siswa dalam penggunaan multimedia pembelajaran interaktif lebih banyak dibandingkan dengan hanya menggunakan buku teks dan gambar saja. Penggunaan multimedia membuat siswa lebih tertarik mengikuti pembelajaran., siswa tampak antusias dengan proses yang dilakukan secara mandiri melalui tampilan yang menarik secara interaktif. Hal ini sesuai dengan pendapat Wahyudi (2009) ketertarikan siswa pada multimedia disebabkan multimedia merupakan sarana pembelajaran yang lebih hidup dan presentative sehigga multimedia banyak membantu siswa dan guru dalam proses pembelajaran.

Berdasarkan hasil uji t menunjukkan ada perbedaan yang signifikan antara siswa yang menggunakan multimedia pembelajaran interaktif terhadap hasil belajar dengan skor rata-rata lebih tinggi daripada kelas kontrol yang menggunakan buku teks saja, dengan perolehan nilai mean $=65.89$ lebih tinggi dari kelas kontrol dengan mean $=53.33$. Hal ini sesuai dengan pendapat Wahyudi (2009) bahwa ada perbedaan skor rata-rata belajar antara siswa yang dilibatkan dalam pembelajaran dengan pemanfaatan multimedia dan tanpa multimedia (menggunakan buku teks). Berdasarkan hasil paparan data dan temuan penelitian didapatkan adanya perbedaan dari penggunaan multimedia pembelajaran interaktif 
pada hasil belajar siswa dengan efek 1,61 >0,8 yang dikategorikan sebagai ukuran efektivitas yang besar.

\section{KESIMPULAN DAN SARAN}

Berdasarkan hasil analisis data dan pembahasan, dapat disimpulkan bahwa ada perbedaan pembelajaran melalui multimedia interaktif dan melalui buku teks terhadap hasil belajar siswa. Hal ini dibuktikan melalui uji hipotesis dengan uji t dan gain ternormalisasi, dimana hasil yang diperoleh pada kelas eksperimen diperoleh mean 65.89 dengan standar deviasi 18.878 lebih besar daripada kelas kontrol yang memiliki mean 53.33 dengan standar deviasi 32.471. Hasil gain score menunjukkan selisih antara nilai pre-test dan post-test didapatkan pada kelas eksperimen dengan hasil rata-rata gain score yaitu $=0,7$ yang masuk dalam kategori tinggi. Sementara itu, hasil perhitungan uji $\mathrm{t}$ didapatkan $\mathrm{t}=2,089$; $F=15,285$ dan signifikansi 2-tail 0,40/0,41 lebih kecil dari signifikansi 0,05, maka Ho ditolakdan Ha diterima. Artinya, ada per-bedaan yang signifikan pada penggunaan multimedia pembelajaran interaktif terhadap hasil belajar siswa di SDN Gadang 01 Malang.

Berdasarkan kesimpulan diatas, maka dapat disarankan hal-hal berikut:

\section{Bagi Guru}

Diharapkan sebagai bahan pertimbangan bagi guru untuk memiliki kreativitas dalam mengembangkan media khususnya pada mata pelajaran matematika. Dalam mempelajari materi operasi hitung berbagai bentuk pecahan hendaknya menggunakan multimedia interaktif. Pada kenyataannya materi operasi hitung berbagai bentuk merupakan materi yang sulit. Banyak siswa yang masih kesulitan dalam memahami konsep operasi hitung berbagai bentuk pecahan. Dengan menggunakan multimedia interaktif diharapkan siswa benarbenar dapat memahami konsep operasi hitung berbagai bentuk pecahan secara menyeluruh.

\section{Bagi Peneliti Lain}

Hasil penelitian ini mungkin jauh dari kesempurnaan, maka untuk peneliti selanjutnya disarankan dapat digunakan sebagai bahan masukan dan perbandingan dalam melaksanakan penelitian yang sejenis dan dapat dikembangkan menjadi lebih baik.

\section{DAFTAR PUSTAKA}

Darmawan. 2013. Metode Penelitian Kuantitatif. Bandung: Remaja Rosdakarya.

Djamarah, SyaifulBahri. 2005. Guru dan Anak Didik dalam Interaksi Edukatif. Jakarta: PT. Rineka Cipta.

Mayer, R.E., 2009. Multimedia Learning: Prinsip-prinsip dan Aplikasi, Yogyakarta: Pustaka Pelajar.

Muslim, A. 2012. Pembelajaran Operasi Hitung Perkalian dan Pembagian Pecahan SD. [Online]. Tersedia di: http://arifinmuslim.files.wordpress.com/2 011/12/pembelajaran-operasi-hitungperkalian-pembagian-pecahan-sd.pdf. Diakses 22 Februari 2016. Sagala, Syaiful. 2010. Konsep \& Makna Pembelajaran. Bandung: Alfabeta.

Sugiyono. 2014. Metode Penelitian Kuantitatif, Kualitatif, dan Kombinasi (Mixed Methods). Bandung: Alfabeta.

Tarigan, Henry Guntur dan Djago Tarigan. 2009. Telaah Buku Teks Bahasa Indonesia. Bandung: Angkasa.

Wahyudi. 2009. Kepemimpinan Kepala Sekolah dalam Organisasi Pembelajaran (Learning Organization). Bandung: Alfabeta 